\title{
COMMENTS
}

\section{THE "ESSENTIAL RELATIONSHIP" SPECTRUM: A FRAMEWORK FOR ADDRESSING CHOICE OF PROCEDURAL LAW IN THE FEDERAL CIRCUIT}

\begin{abstract}
SEAN M. MCELDOWNEY ${ }^{\dagger}$
Because of the Federal Circuit's unique jurisdictional grant, the court faces a unique choice-of-law problem whenever a procedural issue is appealed in a patent suit. Unfortunately, rather than announcing and following a consistent doctrine for choice-of-law questions, the Federal Circuit has developed a menu of phraseology and policy concerns, selecting and then applying a unique combination of appetizer and entrée each time it faces a choice-of-procedural-law question.

What is missing is a consistent conceptual framework. This Comment proposes such a framework, in the form of a conceptual spectrum, along which each choice-of-procedural-law question should be placed. Procedural questions bearing no relation to substantive patent doctrines (by which I mean, primarily, procedural questions that bear no relation to patent validity or infringement doctrines) are at one end of the spectrum, and those bearing a close and "essential" relationship are at the opposite end.

When considering questions in light of this framework, three principles should guide the Federal Circuit. First, each precedential point on the spectrum should be a bright and immovable point, so that each decision is construed to encompass all similar procedural questions. Second, each choice-of-procedurallaw decision should be interpreted not only for its holding on a particular type of procedural question, but also for its holding on the degree of relationship between the procedural question and substantive patent law; in other words, the relevant unit of measure on the spectrum is the closeness of the relationship between a procedural question and substantive patent law. Third, the "essential

\footnotetext{
† B.S. Chemical Engineering, 2000, Washington State University; J.D. Candidate, 2005, University of Pennsylvania Law School. I would like to thank Robert Potter and Brian Ancheta for their excellent suggestions in the editing process. I would also like to thank Professors R. Polk Wagner and Gideon Parchomovsky, for their mentoring over the course of my law school education, and my wife (Luci) and parents (Bernard and Janice), for their support in all my endeavors.
} 
relationship" point on the spectrum should generally require deference to regional circuit law-the Federal Circuit should only forge unique procedural laws when deference to regional circuit law on a particular procedural question would significantly undermine predictable application of the Federal Circuit's substantive patent doctrines.

\section{INTRODUCTION}

Imagine you are outside counsel for a company, and are asked about the joint defense privilege ${ }^{1}$ for a potential patent infringement suit. Your client and one of its competitors recently received notice from a third company, a patent holder, alleging that both your client's and its competitor's products infringe one of the patent holder's patents. To explore the strength of the patent holder's potential infringement suit, your client wants to exchange information with its competitor, but is concerned that doing so might waive privilege for the information they share. You know that in most regional circuits, the joint defense privilege would protect their shared information so long as your client and its competitor have a reasonable expectation of a lawsuit as well as a common legal interest. ${ }^{2}$ However, because the potential suit would be a patent infringement suit, you also know that any appeals from the suit would be heard by the U.S. Court of Appeals for the Federal Circuit—which has never before addressed the joint defense privilege-rather than one of the federal regional circuit courts of appeals. ${ }^{3}$

Consequently, your advice to your client turns on the Federal Circuit's choice-of-law doctrine. Under this doctrine-stated generallythe Federal Circuit defers to regional circuit law for procedural questions that are not sufficiently "unique" or "related" to patent law, or

\footnotetext{
${ }^{1}$ The joint defense privilege is "an extension of the attorney client privilege. It serves to protect the confidentiality of communications passing from one party to the attorney for another party where a joint defense effort or strategy has been decided upon and undertaken by the parties and their respective counsel." United States v. Schwimmer, 892 F.2d 237, 243 (2d Cir. 1989) (internal quotation marks and citation omitted). I choose this procedural question simply because it is one of the many procedural questions the Federal Circuit has not yet squarely addressed.

${ }^{2}$ See, e.g., Sony Elecs., Inc. v. Soundview Techs., Inc., 217 F.R.D. 104, 108 (D. Conn. 2002) (finding that the joint defense privilege applies when a defendant indicates its intent to license or enforce a patent).

${ }^{3}$ See 28 U.S.C. $\$ \$ 1295$ (a) (1), 1338(a) (2000) (giving the Federal Circuit exclusive jurisdiction over suits "arising under" patent law).

${ }^{4}$ Panduit Corp. v. All States Plastic Mfg., 744 F.2d 1564, 1574-75, 1575 n.14 (Fed. Cir. 1984) (per curiam).
} 
that do not "bear[] an essential relationship to" patent law. So you can explain to your client that if the Federal Circuit chooses to defer to regional circuit law on this question, then the usual joint defense rule will apply. However, you must add a significant and unsatisfying caveat: the Federal Circuit might not defer to regional circuit law (perhaps on the theory that finding a reasonable apprehension of litigation turns on the strength of the patent holder's patent rights, and is thereby sufficiently related to patent law). In this case, since the Federal Circuit has never before addressed the joint defense privilege, your guess as to the Federal Circuit's likely decision would be no more than a guess. And to further complicate matters, the district court hearing the infringement suit would have to make the same guess as to choice of procedural law. Thus, despite the potential benefits of sharing information with its competitor, your client proceeds under significant uncertainty and at substantial risk. This is precisely the problem that patent practitioners and district court judges face when considering procedural questions in patent suits.

The problem arises as a result of the Federal Circuit's unique nationwide jurisdictional grant, which gives the court exclusive jurisdiction over appeals from suits "arising under" patent law. ${ }^{6}$ Because the Federal Circuit has jurisdiction to hear the entire case, rather than simply patent law questions, the court faces the problem of determining how it should judge nonpatent issues arising in such appeals. At one extreme, the court could decide to create and apply its own law on all questions, patent and nonpatent. At the other extreme, the court could adopt a rule of complete deference to regional circuit law for all nonpatent issues. Recognizing that the former extreme might introduce unnecessary conflict in nonpatent law, ${ }^{7}$ and that the latter extreme might be at odds with the Federal Circuit's mandate to unify patent law, the court has generally opted for a middle-ground approach-deferring to regional circuit law unless the issue is "unique," "related," or "bears an essential relationship" to patent law. However, in applying its general rule of deference, the court has not only been inconsistent, but has reached too far on many occasions, causing unnecessary confusion and conflict in procedural law. ${ }^{8}$

\footnotetext{
${ }^{5}$ Biodex Corp. v. Loredan Biomed., Inc., 946 F.2d 850, 858-59 (Fed. Cir. 1991).

${ }^{6} \S \S 1295(\mathrm{a})(1), 1338(\mathrm{a})$.

7 See, e.g., Biodex, 946 F.2d at 857 (referring to the "core policy of not creating unnecessary conflicts and confusion in procedural matters").

${ }^{8}$ See infra Part III (discussing the Federal Circuit's choice-of-law precedent).
} 
This Comment analyzes the Federal Circuit's choice-of-law problem with respect to procedural questions arising in patent suits. Part I frames the problem, explaining the origin of the Federal Circuit, its unique jurisdictional grant, and the implications of the choice-of-law problem. Part II discusses the policies and concerns that should guide the Federal Circuit in choosing an appropriate choice-of-law doctrine for procedural questions. Part III explains the Federal Circuit's various formulations of its choice-of-law standard, and highlights some problems with the court's approach. Based on the concerns raised in Parts II and III, Part IV proposes changes to the court's approach, suggesting a workable framework within which each choice-of-law decision would enhance the predictability of future choice-of-law questions, rather than (as seems to be the current trend) contribute to the existing confusion.

\section{PAtent Litigation AND THE FEDERAL CIRCUIT'S JURISDICTION}

To understand the choice-of-procedural-law problem facing the Federal Circuit, we begin with an explanation of the Federal Circuit's jurisdictional grant and how a patent progresses through the administrative and judicial systems.

\section{A. The Federal Circuit}

The Federal Circuit was created as the thirteenth federal appellate court by the Federal Courts Improvement Act of 1982 (FCIA). ${ }^{9}$ Unlike other federal circuit courts, whose jurisdictions are defined geographically, the Federal Circuit is vested with nationwide jurisdiction over certain subject matters. Most important for the purposes of this Comment, the Federal Circuit is vested with jurisdiction over appeals from federal district courts for suits arising under patent law. ${ }^{10}$

Although the focus of this Comment is on the Federal Circuit's role in patent suits, it is important to note that the court's jurisdic-

\footnotetext{
${ }^{9}$ Federal Courts Improvement Act of 1982, Pub. L. No. 97-164, 96 Stat. 25 (codified as amended in scattered sections of 28,35 U.S.C.).

${ }^{10}$ The Federal Circuit has jurisdiction over appeals from district court decisions when the district court's jurisdiction is based, "in whole or in part," on 28 U.S.C. $\S$ 1338. 28 U.S.C. $\$ 1295$ (a)(1) (2000). Section 1338, in pertinent part, gives district courts exclusive original jurisdiction over "any civil action arising under any Act of Congress relating to patents.” Id. § 1338(a).
} 
tional grant includes many other areas of law, such as appeals from the Court of International Trade. ${ }^{11}$

\section{B. Patent Litigation}

The life of a patent begins in the United States Patent and Trademark Office (PTO) with patent prosecution-the process by which an inventor applies for a patent and works with the PTO to obtain an issued patent. Although an applicant can appeal an adverse decision by the PTO to a federal court, this sort of appeal does not raise the choice-of-procedural-law questions that arise in patent infringement suits because the Federal Circuit has exclusive jurisdiction over all issues on appeal. ${ }^{12}$

${ }^{11} I d . \S 1295(\mathrm{a})(5)$. In fact, one source estimates that patent appeals only make up about $27 \%$ (19\% from patent suits in district courts and $8 \%$ from the PTO) of the Federal Circuit's docket, with the majority of the court's docket consisting of appeals from the Merit Systems Protection Board (49\%) and the Court of Federal Claims (11\%). Donald S. Chisum et Al., PRinciples of Patent LaW 28-30 (2d ed. 2001). Of course, because they are based only on the number of cases heard by the Federal Circuit, these statistics miss the fact that patent appeals are often lengthy and therefore might account for a more significant portion of the court's time. Id. at 28.

${ }^{12}$ An applicant can appeal a PTO decision within the PTO to the Board of Patent Appeals and Interferences, 35 U.S.C. § 6(b) (2000), and ultimately to a federal court. Between 1929 and 1982, such appeals were heard by the Court of Customs and Patent Appeals (CCPA). See Act of Mar. 7, 1929, Pub. L. No. 70-914, 45 Stat. 1475, 1475-76 (establishing the CCPA). Since 1982, appeals from a PTO rejection have been heard by the Federal Circuit. 35 U.S.C. $\$ 141$ (2005). Rejections in the PTO can be based on procedural PTO rules, see, e.g., 35 U.S.C. $\$ 185$ (2000) (prohibiting the grant of a patent to a person who has filed a foreign patent application and failed to obtain a required license from the PTO), or substantive patent law, see, e.g., $i d$. $§ 102$ (defining the novelty requirement for patentability of an invention). In either case, however, the issues on appeal are truly unique to patent law or patent prosecution. Furthermore, because patent prosecution is an ex parte process, see, e.g., Hercules Inc. v. Exxon Corp., 434 F. Supp. 136, 152 (D. Del. 1977) ("The prosecution of an application before the Patent Office is not an adversary, but an ex parte proceeding."), and because such appeals are appeals from an administrative agency rather than from a trial court, these cases do not raise the same procedural questions that arise in patent infringement suits heard by district courts. Consequently, transferring appeals from the PTO to the Federal Circuit created no jurisdictional or choice-of-law confusion-the Federal Circuit has exclusive jurisdiction over all issues raised on appeal.

Indeed, the Federal Circuit has always maintained that it has exclusive authority to follow and create its own law for all matters in cases where it has truly exclusive jurisdiction over appeals. For example, the court has noted that it may "creat[e] new law regarding any and all matters in cases where this court has exclusive jurisdiction over all appeals from a particular court [such as the Court of International Trade]." Panduit Corp. v. All States Plastic Mfg., 744 F.2d 1564, 1575 (Fed. Cir. 1984) (per curiam). Presumably this applies to appeals from the PTO as well, given that the Federal Circuit has exclusive ultimate jurisdiction, either directly from the PTO or after a ruling in the 
Once issued, a patent can become the subject of litigation in various ways; most commonly, the patentee brings an infringement suit against a party she believes has made, sold, or used the patented device or method without the patentee's consent. ${ }^{13}$ Other types of suits that are substantively similar to patent infringement suits can also bring a patent to the center of litigation (e.g., a declaratory judgment suit). However, in addition to these suits, which lie at the heart of substantive patent law, patents can become the subject of litigation in myriad other ways that do not implicate substantive patent law to the same extent. For instance, patents are often central to trade dress infringement, antitrust, and licensing dispute suits. ${ }^{14}$

Prior to 1982, regardless of the subject matter of a lawsuit, the geographically appropriate regional circuit heard the appeal and had exclusive jurisdiction to rule on all questions raised in the case-both patent and nonpatent. However, because appeals from suits "arising under" patent law are now heard by the Federal Circuit, there are two questions that must be addressed in any suit that arguably arises under patent law. The first question asks which cases should be appealed to the Federal Circuit rather than the regional circuit court. Although an evolving doctrine, this question has been addressed in a variety of circumstances and extensively debated among scholars. ${ }^{15}$

Once a court decides that a particular case should be appealed to the Federal Circuit, the second question, a choice-of-law question, arises: whose law should the Federal Circuit apply to questions outside the scope of patent law? Should the Federal Circuit develop its own body of law to address substantive questions of antitrust law and procedural questions regarding discovery disputes? Although the

District Court for the District of Columbia, over appeals from the PTO. See 35 U.S.C. $\$ \S 145-146$ (2005) (providing for suit by patent applicants against the PTO in the District Court for the District of Columbia); supra Part I.A (discussing the Federal Circuit's appellate jurisdiction).

${ }^{13}$ See 35 U.S.C. $\$ 271$ (a) (2000) (defining patent infringement).

${ }^{14}$ See, e.g., Intergraph Corp. v. Intel Corp., 253 F.3d 695, 697 (Fed. Cir. 2001) (discussing patents in relation to an antitrust claim).

${ }^{15}$ The general rule is that a case is appealable to the Federal Circuit if it appears from the well-pleaded complaint that the case arises under patent law. Christianson v. Colt Indus. Operating Corp., 486 U.S. 800, 809 (1988). See generally Emmette F. Hale, III, The "Arising Under" Jurisdiction of the Federal Circuit: An Opportunity for Uniformity in Patent Law, 14 FLA. ST. U. L. REV. 229 (1986) (arguing that the Federal Circuit should abandon the well-pleaded complaint rule); Elizabeth I. Rogers, The Phoenix Precedents: The Unexpected Rebirth of Regional Circuit Jurisdiction over Patent Appeals and the Need for a Considered Congressional Response, 16 HARV. J.L. \& TECH. 411, 448-72 (2003) (arguing that Congress should consider alternatives to the well-pleaded complaint rule in cases involving issues of patent law). 
courts have addressed this question on many occasions, ${ }^{16}$ and scholars have addressed it on a few occasions, ${ }^{17}$ the Federal Circuit's choice-oflaw doctrine remains elusive and ever-changing. The court seems to employ a unique combination of phraseology and policy each time it faces a choice of procedural law. ${ }^{18}$ In its choice-of-procedural-law opinions, the court seems anxious to reach the underlying substance of each suit, and is content to dispose of the choice of procedural law casually and quickly. ${ }^{19}$

\section{Implications of the Choice-of-Procedural-Law Problem}

Given that federal courts are guided by uniform rules of procedure, ${ }^{20}$ and bound by Supreme Court interpretation of those rules, one might surmise that there is little or no real "choice" of procedural law to be made among federal courts. In other words, there should be little difference in procedural law among the circuits, and so whether the Federal Circuit chooses to follow Fifth Circuit procedure or forge its own procedural law, the result will be the same. In fact, though, the choice of procedural law matters very much. Indeed, the very existence of the Federal Circuit's choice-of-procedural-law doctrine suggests that the court itself recognizes the importance of this choice, and for good reason.

First, there are many instances where circuits have disagreed, and continue to disagree, as to specific procedural rules. For instance, prior to the inception of the Federal Circuit, the regional circuits dif-

${ }^{16}$ See infra Part III (discussing the Federal Circuit's choice-of-law precedent).

17 See infra Part IV.A.

${ }_{18}$ See infra Part III.

${ }^{19}$ For example, in Phonometrics, Inc. v. Hospitality Franchise Systems, Inc., 203 F.3d 790 (Fed. Cir. 2000), the Federal Circuit was asked to consider the finality of a district court's dismissal pursuant to a 12(b) (6) motion. Although the court acknowledged that resolution of this issue required it to choose between Federal Circuit and regional circuit law, the court disposed of this choice in a single sentence: "Because the finality of the dismissal in this case is a procedural issue not related to patent law, this court applies the law of the regional circuit, the Eleventh Circuit." Id. at 793. The only support for this conclusion is a citation to Midwest Industries v. Karavan Trailers, Inc., 175 F.3d 1356 (Fed. Cir. 1999) (en banc in part, panel opinion in part), as if Midwest definitively settles the choice of law on the finality of a 12(b) (6) ruling. But Midwest involved a choice of law on the question of whether a state law preempted federal patent law, $i d$. at 1359, a question that bears little resemblance to the one presented in Phonometrics. Unfortunately, in its choice-of-procedural-law opinions, the Federal Circuit frequently resorts to this method of reasoning, citing precedent that is remotely relevant to fill logical gaps.

${ }^{20}$ For example, the Federal Rules of Civil Procedure and Federal Rules of Evidence. 
fered substantially on the scope of attorney-client privilege with respect to patent prosecution documents. ${ }^{21}$ More recently-as just one of many examples-circuits have explicitly disagreed as to whether an award of attorney's fees is appealable before the district court has quantified the award. ${ }^{22}$ In such cases, where there are conceivably multiple procedural rules available to a court, the choice of law obviously matters.

Even when there is only one widely accepted formulation of the proper procedural rule, the choice of procedural law still matters, and the Federal Circuit has recognized as much in certain cases. For instance, when a district court grants or denies a party's motion to amend its pleadings, circuits agree that the proper standard of review on appeal is "abuse of discretion." ${ }^{23}$ So, there is no "choice" to be made as to the proper formulation of the rule. Nonetheless, the Federal Circuit has, implicitly, recognized that the choice of law still matters. Though the court deferred to Fifth Circuit law when reviewing the ability of a plaintiff to amend its complaint, ${ }^{24}$ it chose to forge its own law when reviewing the ability of a defendant to amend its answer. $^{25}$ Despite the fact that, at least ostensibly, the procedural standard would be the same no matter the choice of law (i.e., an abuse of discretion standard), the court still believed that the choice mattered.

The critical insight here is that a court's choice of procedural law is not merely a choice among possible formulations of a procedural rule, but also a choice to bind itself to a particular set of procedural precedents. If the court chooses regional circuit law, then not only

${ }^{21}$ See infra notes 75-80 and accompanying text (describing the evolution of two theories of attorney-client privilege regarding patent prosecution documents).

${ }^{22}$ The Seventh Circuit, "in the interest of orderly judicial administration," has granted such an appeal. Bittner v. Sadoff \& Rudoy Indus., 728 F.2d 820, 826 (7th Cir. 1984) (quoting Scarlett v. Seaboard Coast Line R.R., 676 F.2d 1043, 1052 (5th Cir. 1982)). Most other circuits, including the Federal Circuit, have denied such appeals, on the theory that it is more efficient to review the amount of the award along with the fact of the award because the two questions are so intertwined. See Special Devices, Inc. v. OEA, Inc., 269 F.3d 1340, 1343-45 (Fed. Cir. 2001) (choosing to create its own law on the question of appealing an unquantified award of attorney fees and discussing the approach taken in several other circuits).

${ }^{23}$ See, e.g., Advanced Cardiovascular Sys., Inc. v. Medtronic, Inc., 265 F.3d 1294, 1303 (Fed. Cir. 2001) (applying the Federal Circuit's abuse of discretion standard of review); Norman v. Apache Corp., 19 F.3d 1017, 1021 (5th Cir. 1994) (applying the Fifth Circuit's abuse of discretion standard of review).

${ }^{24}$ Ferguson Beauregard/Logic Controls v. Mega Sys., LLC, 350 F.3d 1327, 1342 (Fed. Cir. 2003)

${ }^{25}$ Advanced Cardiovascular, 265 F.3d at 1303. 
should the court adopt the regional circuit's formulation of the relevant rule, but also that circuit's precedent, which guides the application and interpretation of the rule.

Unfortunately, the Federal Circuit seems to ignore this insight in many of its cases. ${ }^{26}$ This has caused the court to approach choice-ofprocedural-law questions too casually, resulting in inconsistent and incoherent application of its own choice-of-law doctrine. The result can be that procedural law in the Federal Circuit, subtly and perhaps unconsciously, diverges from procedural law in the regional circuits. For instance, in the case of attorney-client privilege, the Federal Circuit's drift away from regional circuit law culminated in In re Spalding Sports Worldwide, Inc., ${ }^{27}$ where the court seemingly expanded the scope of attorney-client privilege over patent prosecution documents. ${ }^{28} \mathrm{Be}-$ cause the Federal Circuit tried to limit its holding to a very narrow range of attorney-client privilege questions, litigants and district courts are now left wondering when to apply the Federal Circuit's broader interpretation of attorney-client privilege and when to apply regional circuit law.

Failing to recognize this important implication of its choice of procedural law, the Federal Circuit risks confusion by intermingling regional circuit rules with its own precedent, and vice versa. Not only do litigants and district courts need clear direction as to which rule applies, but also they must know which precedent is relevant and binding with regard to application of the rule. Without clear guidance on this choice, district courts are forced to "serve two masters"

${ }^{26}$ For instance, in Fonar Corp. v. Johnson Eु Johnson, 821 F.2d 627, 631 (Fed. Cir. 1987), overruled on other grounds by Cardinal Chemical Co. v. Morton International, Inc., 508 U.S. 83 (1993), the court reviewed a grant of a motion for judgment notwithstanding the verdict (JNOV), and found that the nonmoving party "must show that there was substantial evidence to support the jury's findings." So clear was the law in this regard that the Federal Circuit failed to even address the choice of procedural law that it faced (a choice between First Circuit law and its own), simply citing its own case law and the First Circuit's case law to show that the two followed an identical standard. Id.

27203 F.3d 800 (Fed. Cir. 2000).

${ }^{28}$ See id. at $806 \&$ n.3 (holding that, despite the fact that several district courts routinely followed a different rule, an invention record is "privileged in its entirety" when it is "prepared and submitted primarily for the purpose of obtaining legal advice on patentability and legal services in preparing a patent application"); see also Note, Attorney-Client Privilege in Patent Litigation: Did the Federal Circuit Go Far Enough with In re Spalding Sports Worldwide?, 55 OKLA. L. REV. 731, 731 (2002) (arguing that the Federal Circuit "chose the correct path in extending the privilege to most legal communications between client and patent attorney").

${ }^{29}$ See Atari, Inc. v. JS \& A Group, Inc., 747 F.2d 1422, 1439 (Fed. Cir. 1984) (en banc) (noting in the context of the Federal Circuit's choice of law that "[i]t would be 
and litigants are forced to plan their primary activities and litigation strategies with an eye toward two potential sets of procedural laws and precedents.

\section{CONSiderations that SHOUld Guide THE FederaL CIRCUIT'S CHOICE-OF-LAW DOCTRINE}

The Federal Circuit's mandate from Congress is to facilitate nationwide uniformity in "patent law." ${ }^{30}$ On close reading, though, the scope of this goal (i.e., the scope of patent law, for which the Federal circuit is to facilitate uniformity) is ambiguous in both the court's enabling legislation ${ }^{31}$ and its precedent. Is the court to promote uniformity in all aspects of patent trials? All aspects of patent appeals? All aspects of law that pertain to or affect patent law? Or is the court's mandate limited to interpreting the patent statute? Following are discussions of the court's enabling legislation and policy considerations that should dictate the scope of the court's mandate.

\section{A. Legislative History}

In concluding that patent appeals should be centralized in a court with nationwide jurisdiction, Congress relied on the Commission on Revision of the Federal Court Appellate System (Hruska Commission) and testimony by "distinguished jurists, patent practitioners, and representatives of major technologically-oriented business enterprises [confirming] that patent cases are inconsistently adjudicated." ${ }^{32}$

The Hruska Commission, relying on Professors James Gambrell and Donald Dunner as patent law consultants, concluded that " $[\mathrm{t}] \mathrm{he}$ problem [of predictability and consistency throughout the country]

\footnotetext{
at best unfair to hold in this case that the district court, at risk of error, should have 'served two masters,' or that it should have looked, Janus-like, in two directions in its conduct of that judicial process"), overruled on other grounds by Nobelpharma AB v. Implant Innovations, Inc., 141 F.3d 1059 (Fed. Cir. 1998) (en banc).

${ }^{30}$ See S. REP. NO. 97-275, at 2, 4-5 (1981), reprinted in 1982 U.S.C.C.A.N. 11, 12, 15 (noting that the purpose of the bill, which creates the Federal Circuit, is to "fill a void in the judicial system by creating an appellate forum capable of exercising nationwide jurisdiction over appeals in areas of the law where Congress determines there is a special need for nationwide uniformity," including patent law).

${ }^{31}$ Federal Courts Improvement Act of 1982, Pub. L. No. 97-164, 96 Stat. 25 (codified, inter alia, in scattered sections of 28,35 U.S.C.).

${ }^{32}$ S. REP. No. 97-275, at 5 (1981), reprinted in 1982 U.S.C.C.A.N. 11, 15.
} 
has been particularly acute in the field of patent law."33 Notably, though, the only such nonuniformity cited in the Commission's report and its patent consultants' appendix was a disparity in regional circuits' interpretation of the nonobviousness requirement-one of the core substantive requirements for patent validity. ${ }^{34}$

The concerns raised by the jurists, practitioners, and businesspersons to whom Congress referred were also quite limited, alleging that patent infringement and validity were the areas of nonuniformity. ${ }^{35}$ For those who supported the notion of centralizing patent appeals, the underlying motivation was that "[s]ignificant economic decisions are made from time to time based upon the existence or the lack of pat-

33 COMM'N ON REVISION OF THE FED. COURT APPELlate SYS., RECOMMENDATIONS FOR CHANGE (1975), reprinted in 67 F.R.D. 195, 220 [hereinafter HRUSKA COMMISSION REPORT].

${ }^{34}$ See 35 U.S.C. $\$ 103(\mathrm{a})$ (2000) (stating that a patent is invalid "if the differences between the subject matter sought to be patented and the prior art are such that the subject matter as a whole would have been obvious at the time the invention was made to a person having ordinary skill in the art" (emphasis added)).

${ }^{35}$ See, e.g., Federal Courts Improvement Act of 1979: Hearings on S. 677 and S. 678 Before the Senate Subcomm. on Improvements in Judicial Mach. of the Comm. on the Judiciary, 96th Cong. 33 (1979) [hereinafter 1979 Hearings] (statement of Daniel J. Meador, Assistant Attorney General, Department of Justice) ("The validity of a patent should not turn upon the happenstance of who wins the race to the courthouse door."); $i d$. at 113 (statement of Hon. Howard T. Markey, Chief Judge, Court of Customs and Patent Appeals) (asserting a "crying need for definitive, uniform, judicial interpretation of [the patent statutes]"); id. at 531-33 (letter from Phillip H. Mayer of Leydig, Voit, Osann, Mayer \& Holt, Ltd.) (describing two examples of nonuniformity in regional circuit court decisions: the "synergism test" and the appropriate date on which to base prior art determinations, both of which relate to validity of a patent); Position Paper of Bar Association of the Seventh Federal Circuit on S-677 and S-678, at ii, submitted under cover letter from Harold R. Woodward, President, Bar Association of the Seventh Federal Circuit, to Senator Dennis DeConcini, reprinted in 1979 Hearings, supra, at 659, 664 (" $[\mathrm{I}] \mathrm{t}$ is only with respect to the 35 U.S.C. $\S 103$ obviousness cases that it is claimed that there is a lack of uniformity."); Federal Courts Improvement Act of 1979: Addendum to Hearings on S. 677 and S. 678 Before the Senate Subcomm. on Improvements in Judicial Mach. of the Comm. on the Judiciary, 96th Cong. 49 (1979) [hereinafter Addendum to 1979 Hearings] (statement of Hon. Jack Miller, Judge, Court of Customs and Patents Appeals) (suggesting that the regional circuit courts should transfer questions of infringement and validity to a centralized court); $i d$. at 56 (statement of Donald R. Dunner, patent consultant to the Hruska Commission) (" $[\mathrm{T}]$ here has been a wide variety of views among the circuits as to the nature of the test to be applied to determine whether patentable invention exists.”); $i d$. at 67 (statement of Harry F. Manbeck, Jr., general patent counsel of General Electric Co.) ("The businessman wants to know if a patent is likely to be sustained or overturned and not that his chances are at one percentage level if the trial occurs in one circuit and at another percentage level if it occurs in another circuit."); $i d$. at 72 (statement of Richard C. Witte, chief patent counsel of Proctor \& Gamble Co.) (describing a survey of industry researchers showing that eighty-four percent of the respondents felt that variance in the court's standards of patentability is eroding the value of the patent incentive). 
ent coverage" ${ }^{36}$ and "[w] hen decisions are being made [in the board room], the gambler's spirit is low." ${ }^{37}$

The Senate found this argument convincing, noting that "[b] usiness planning will become easier as more stable and predictable law is introduced[, which] can have important ramifications upon our economy as a whole." ${ }^{38}$ These concerns about the adverse effect of inconsistent patent interpretations on innovation are limited to the predictability of validity and infringement decisions-in choosing whether and how to pursue intellectual property, practitioners and businesspersons are concerned with whether their patent is valid, or whether they will be found to have infringed a competitor's patent. In fact, the only testimony alluding to the new court's capacity to hear nonpatent matters concluded that the new court would not be wellequipped to hear such matters. ${ }^{39}$

Thus, Congress only contemplated the Federal Circuit as a tool for facilitating uniformity in patent validity and infringement interpretations. The underlying concern behind this mandate is expressed in the oft-repeated story where then-Judge Thurgood Marshall, in a discussion before his Supreme Court confirmation hearing, quipped: "I haven't given patents much thought, Senator, because I'm from the Second Circuit, and as you know we don't uphold patents in the Sec-

${ }^{36}$ Addendum to 1979 Hearings, supra note 35, at 67 (statement of Harry F. Manbeck, Jr., general patent counsel of General Electric Co.).

${ }^{37} I$. at 56 (statement of Donald R. Dunner, patent consultant to the Hruska Commission).

${ }^{38}$ S. REP. NO. 97-275, at 6 (1981), reprinted in 1982 U.S.C.C.A.N. 11, 16.

${ }^{39}$ See 1979 Hearings, supra note 35, at 26 (statement of Judge Jon O. Newman, U.S. District Court for the District of Connecticut) ("Since patent cases often involve antitrust claims or defenses not necessarily appropriate for a court of patent expertise, it might be appropriate to modify the proposal in those cases where ... the trial judge has severed for separate trial the issues that concern only patent validity and infringement.”); id. at 272 (prepared written statement of Standish F. Medina, Jr., Chairman, Committee on Federal Courts, Association of the Bar of the City of New York) ("[I]t is possible that creation of the new court could lead to ... review by the new court of pendant claims more appropriately decided in the circuit courts."); $i d$. at 541 (letter from Phillip H. Mayer of Leydig, Voit, Osann, Mayer \& Holt, Ltd.) ("The new court would not be as adept or experienced in reviewing trial practices and procedures as would a 'regular' circuit court."); Addendum to 1979 Hearings, supra note 35, at 49 (statement of Hon. Jack Miller, Judge, Court of Customs and Patents Appeals) ("It may well be that [the proposal] goes too far in transferring from the circuits any case that involves a patent infringement or patent validity question. Many of such cases are antitrust cases, which the circuit courts are probably more capable of handling than the proposed new court."). 
ond Circuit." ${ }^{40}$ Matters beyond patent validity and infringement were either not considered by Congress, or were not considered appropriate for Federal Circuit jurisdiction. Indeed, the court itself has recognized that for matters beyond substantive patent law, it has no congressional mandate to unify the law. ${ }^{41}$

In addition to promoting research and development by stabilizing patent law, the other primary motivation for seeking uniformity in patent law was to reduce forum shopping-a concern raised by the Hruska Commission ${ }^{42}$ and reiterated by the Senate. ${ }^{43}$ However, the forum shopping at issue was spurred by the disparity among regional circuits in interpreting validity and infringement. For instance, the Hruska Commission summarized the nature of forum shopping in patent cases, noting that "[p]atentees now scramble to get into the 5 th, 6th and 7th circuits since the courts there are not inhospitable to patents whereas infringers scramble to get anywhere but in these circuits." ${ }^{44}$

Thus, although the choice-of-law question was not explicitly addressed in the Federal Circuit's enabling legislation, it is clear from the legislative history that the court's inception was motivated by and directed at facilitating uniformity in the interpretation and application of validity and infringement. The fundamental concern was that unpredictability in patent law undermined innovation in our nation's industrial sector. ${ }^{45}$ But Congress struck a careful balance when creat-

${ }^{40}$ Hon. Gerald J. Mossinghoff, Side Bar: The Creation of the Federal Circuit, in CHISUM ET AL., supra note 11, at 30, 31 .

${ }^{41}$ See Bandag, Inc. v. Al Bolser's Tire Stores, Inc., 750 F.2d 903, 909 (Fed. Cir. 1984) ("No mandate to unify intercircuit conflicts regarding [nonpatent] matters was given to this court by Congress in its passage of our enabling legislation ....").

${ }^{42}$ See HRUSKA COMMISSION REPORT, supra note 33, at 220 ("[D] isparity in results in different circuits leads to widespread forum shopping .... [which] 'demeans the entire judicial process and the patent system as well.'”) (quoting James B. Gambrell and Donald R. Dunner).

${ }^{43}$ See S. REP. NO. 97-275, at 5 (1981), reprinted in 1982 U.S.C.C.A.N. 11, 15 ("Uniformity will reduce the forum-shopping that is common to patent litigation.... [which] will reduce costs to litigants and will also be a positive improvement from the standpoint of the judicial system.").

${ }^{44}$ HrUSKa COMmission RePORT, supra note 33, at 370 (quoting a letter to the Commission by James B. Gambrell and Donald R. Dunner).

${ }^{45}$ See 1979 Hearings, supra note 35, at 113 (statement of Hon. Howard T. Markey, Chief Judge, Court of Customs and Patent Appeals) ("The problem originally addressed in the proposal was the nonuniformity in interpretation and application of the ... patent laws of our Nation ...."); see also Markman v. Westview Instruments, Inc., 517 U.S. 370, 390 (1996) ("It was just for the sake of such desirable uniformity that Congress created the Court of Appeals for the Federal Circuit as an exclusive appellate court for patent cases ...."). 
ing the court. On the one hand, Congress was persuaded by the need to centralize interpretations of validity and infringement, acknowledging that objections to this goal can "hardly counterbalance the potential advantages of a national court having exclusive patent jurisdiction." Such a court, it was thought, "cannot help but have a stabilizing influence in the interpretation and application of the patent laws and increase industry's confidence and reliance upon the patent grant, the cornerstone of the innovation system." On the other hand, Congress limited the court's mandate to unifying patent law-implicitly recognizing that the regional circuit courts are better equipped to handle nonpatent questions.

\section{B. Policy Considerations for Choosing the Appropriate Choice-of-Law Doctrine}

Inevitably, the Federal Circuit must adopt some choice-of-law rule to handle procedural questions in patent appeals. The choices range from complete deference to regional circuit law, to a rule where the Federal Circuit rules independently on each procedural question arising in the patent appeals it hears. So the question becomes, absent explicit instructions from Congress, where on this spectrum should the Federal Circuit aim?

The answer to this question turns on policy concerns. In its case law, the Federal Circuit seems to pick and choose among a few primary policy concerns, ${ }^{47}$ relying on one policy goal in one case, and then a different policy concern in the next, ${ }^{48}$ never tackling a single case with the full arsenal of necessary policy concerns or prioritizing the few policy concerns that it addresses in a single case. ${ }^{49}$ The result

${ }^{46}$ Addendum to 1979 Hearings, supra note 35, at 57 (statement of Donald R. Dunner, patent consultant to the Hruska Commission).

${ }^{47}$ The three primary policy concerns to which the Federal Circuit has looked in considering choice-of-procedural-law questions are the goal of achieving uniformity in patent law, the policy of avoiding unnecessary conflicts in procedural law, and the concern of avoiding confusion for district court judges in administering patent trials. See infra text accompanying notes 110-12.

${ }^{48}$ Compare In re Spalding Sports Worldwide, Inc., 203 F.3d 800, 803-04 (Fed. Cir. 2000) (focusing on how the choice of law for attorney-client privilege affects the Federal Circuit's mandate to unify substantive patent law, but failing to address its implications on uniformity in procedural law), with Transmatic, Inc. v. Gulton Indus., 180 F.3d 1343, 1347-48 (Fed. Cir. 1999) (weighing, in some detail, the balance of the Federal Circuit's interest in achieving uniformity in patent law with the general judicial interest of maintaining uniformity in procedural law).

${ }^{49}$ In addressing choice-of-law questions, the Federal Circuit has limited its policy considerations to the goal of achieving uniformity in the patent law and the impor- 
is not only the inconsistent and unpredictable application of the court's choice-of-law rule, but also a developing body of precedent that fails to account for the full spectrum of interests.

Conceptually, the Federal Circuit's choice-of-law doctrine will affect three distinct groups of interests: potential litigants, courts, and the effectiveness and quality of the law itself. These interests are considered, in turn, below.

\section{Impact on Potential Litigants and Practitioners}

A litigant's primary concern is often predictability of the law ${ }^{50}-$ regardless of the substance of the law. Businesses can manage around adversity (i.e., a "bad" law) with appropriate planning and counseling, but fare far worse when faced with uncertainty. Lawyers must be able to advise their clients with reasonable clarity and confidence, and businesses must be able to rely on that advice when they manage daily activities and plan for the future. Indeed, "[t] he most important value of the rule of law is in the provision of a stable and reliable framework for behavior, and the avoidance of litigation. ${ }^{51}$

tance of avoiding unnecessary confusion in procedural law. See, e.g., Biodex Corp. v. Loredan Biomed., Inc., 946 F.2d 850, 859 (Fed. Cir. 1991) (asserting that the Federal Circuit's choice-of-law doctrine should further the goal of achieving " $[u]$ niformity in the review of patent trials"); $i d$. at 857 (referring to "the core policy of not creating unnecessary conflicts and confusion in procedural matters"). While these two concerns may be of primary importance, other policy considerations should, at a minimum, be added to the court's analyses. For instance, the court has rarely, if ever, directly addressed the interest of keeping patent law in the mainstream of jurisprudence. One of the court's few references to this concern is in a dissenting opinion for a case in which the majority failed to even acknowledge that it was faced with a choice-of-law question. See Ohio Cellular Prods. Corp. v. Adams USA, Inc., 175 F.3d 1343, 1355 (Fed. Cir. 1999) (Newman, J., dissenting) (noting that the majority's decision, which permitted plaintiff to add a third party defendant to their complaint after a final judgment awarding attorneys fees, "further move[s] patent cases from the mainstream of ... procedural law"), rev'd and remanded on other grounds by Nelson v. Adams USA, Inc., 529 U.S. 460 (2000).

Likewise, many scholars addressing the Federal Circuit's choice-of-law doctrine have also focused on these two policy goals at the expense of others. See infra Part IV.A.

${ }^{50}$ See, e.g., Joel P. Trachtman, Economic Analysis of Prescriptive Jurisdiction, 42 VA. J. INT'L L. 1, 51 (2001) (explaining the importance of the law's predictability to litigants both ex ante-so "persons subject to the law [are] able to plan and conform their conduct" - and ex post-so parties can "predict the tribunal's determination of their respective rights and duties" and thus spend less money on litigation).

${ }^{51}$ Hon. Pauline Newman, The Federal Circuit: Judicial Stability or Judicial Activism?, 42 AM. U. L. REV. 683, 687 (1993). 
Predictability of substantive patent law is at the heart of the Federal Circuit's mandate. ${ }^{52}$ However, the need for predictability is not unique to substantive patent law; indeed, the need for predictability in procedural law is arguably more important. For instance, the effect of an unexpected attorney-client privilege ruling, compelling a litigant to produce documents that they have long believed were protected, may be more devastating than an unexpected finding of patent invalidity. Whereas an adverse ruling on the validity of a patent only affects the value of the firm's intellectual property portfolio, an adverse ruling on discovery of documents makes it more likely that the documents will be accessible to the public, including adverse parties in future litigation. $^{53}$ Other procedural questions, such as personal jurisdiction ${ }^{54}$ or pleading requirements, ${ }^{55}$ can have similarly far-reaching effects. In other words, procedural questions can impact every aspect of a company's activities, whereas patent outcomes might only implicate the value of a particular patent.

So, in choosing and applying the appropriate choice-of-law rule, the need for uniformity and predictability in procedural law should be given at least the same consideration as the need for uniformity in substantive patent law.

\section{Impact on the Administration of Trials and Appellate Review}

\section{a. District courts}

Just as potential litigants have an interest in the predictability of the law, so too do district court judges. Of primary concern to these

52 See supra Part II.A.

53 See, e.g., Nixon v. Warner Communications, Inc., 435 U.S. 589, 597 (1978) ("It is clear that the courts of this country recognize a general right to inspect and copy public records and documents, including judicial records and documents." (footnote omitted)). But see Chi. Tribune Co. v. Bridgestone/Firestone, Inc., 263 F.3d 1304, 1311 (11th Cir. 2001) (per curiam) ("The right to inspect and copy is not absolute . . ." (citing Nixon, 435 U.S. at 597)); id. ("[For] discovery material . . there is no common-law right of access, as these materials are neither public documents nor judicial records." (citing McCarty v. Barnett Bank of Polk County, 876 F.2d 89, 91 (11th Cir. 1989))); FED. R. CIV. P. 26(c) (providing for the entry of protective orders).

54 See, e.g., Elecs. for Imaging, Inc. v. Coyle, 340 F.3d 1344, 1348 (Fed. Cir. 2003) (applying Federal Circuit law to the question of personal jurisdiction on a claim for declaration of patent invalidity).

55 See, e.g., Advanced Cardiovascular Sys., Inc. v. Medtronic, Inc., 265 F.3d 1294, 1303 (Fed. Cir. 2001) (discussing when the Federal Circuit will apply its own law rather than the law of the regional circuit to questions involving pleading requirements). 
judges is that in patent trials they may be required to "serve two masters" practical perspective, uniformity of patent law is not particularly problematic for district courts because they look, without question, to federal circuit precedent for patent validity and infringement issues. Although there might be internal conflicts in Federal Circuit precedent, there are no intercircuit conflicts, and no confusion over choice of patent law.

But on nonpatent issues arising in patent suits, the Federal Circuit's choice-of-law doctrine requires district courts to decide whether they ought to follow regional circuit precedent or look to Federal Circuit precedent. $^{57}$ To ease the burden of choosing between regional circuit and Federal Circuit precedent, district courts should prefer bright-line decisions giving maximum deference to regional circuit law, since they are most familiar with the law of their own respective circuits.

\section{b. Federal Circuit}

Whatever choice-of-law rule the Federal Circuit adopts will affect the administration of patent appeals. Obviously, the more complicated the choice-of-law rule, the more time consuming its application. From the perspective of administering patent appeals in the Federal Circuit, the court should opt for relatively bright-line rulings that will serve as guideposts for future cases.

\section{c. Supreme Court}

A choice-of-law rule that favors Federal Circuit precedent over regional circuit precedent could undermine the supremacy of Supreme Court rulings on procedural matters. ${ }^{58}$ As a general rule, when the

${ }^{56}$ Atari, Inc. v. JS \& A Group, Inc., 747 F.2d 1422, 1439 (Fed. Cir. 1984) (en banc), overruled on other grounds by Nobelpharma AB v. Implant Innovations, Inc., 141 F.3d 1059 (Fed. Cir. 1998) (en banc).

${ }^{57}$ Compare Transmatic, Inc. v. Gulton Indus., 180 F.3d 1343, 1348 (Fed. Cir. 1999) (applying Sixth Circuit law to determine the appropriate calculation of interest on a damages award), with In re Spalding Sports Worldwide, Inc., 203 F.3d 800, 802 (Fed. Cir. 2000) (applying Federal Circuit law to determine whether certain documents were protected by attorney-client privilege), and Biodex Corp. v. Loredan Biomed., Inc., 946 F.2d 850, 859 (applying Federal Circuit law to determine whether a postverdict motion was required to preserve appellate review of a jury verdict).

${ }^{58}$ Cf. Rochelle Cooper Dreyfuss, The Federal Circuit: A Case Study in Specialized Courts, 64 N.Y.U. L. REV. 1, 61 (1989) ("If the [Federal Circuit] were empowered to adopt its own interpretation of open questions of federal law, then the question arises 
Supreme Court rules on a particular procedural question, that ruling binds all federal courts. However, if the Federal Circuit chooses not to defer to regional circuit law on a particular procedural question, it does so under the theory that the question has some unique relationship to patent law. When the Supreme Court rules on this same question in a nonpatent suit, the ruling is not made in light of this purportedly unique relationship to patent law. In such a case, the Supreme Court could only bind the Federal Circuit's interpretation of that procedural question by hearing the question directly on appeal from the Federal Circuit itself. Supreme Court rulings on appeal from regional circuit courts would not account for the unique relationship to patent law, and so could be considered inapplicable.

Because of this effect, the Federal Circuit should only rule on procedural questions when Supreme Court review of the question on appeal from a regional circuit court would be inapposite to the same procedural question when it is raised in a patent trial. Generally speaking, this militates in favor of deference to regional circuit law.

\section{Impact on the Effectiveness and Quality of the Law}

\section{a. Uniformity in the law}

Because the Federal Circuit's mandate is to achieve uniformity in patent law (i.e., interpretation and application of patent validity and infringement), ${ }^{59}$ any choice-of-law rule should, at least to the extent that it does not conflict with other more fundamental judicial policies, adhere to this mandate. Some scholars have taken this mandate to suggest that the Federal Circuit should develop its own body of law for any and all questions that come before the court-procedural or substantive, patent or nonpatent. ${ }^{60}$ However, the limited scope of the mandate does not require such broad exercise of the court's lawmaking power. Instead, the mandate only requires the court to exercise independent judgment when a particular question bears on the predictability of validity or infringement interpretations.

Moreover, the Federal Circuit's mandate does not necessarily rank primacy over other policies. As the court noted in Biodex, its choice-of-

\footnotetext{
whether it should be permitted to reconsider settled issues in light of its unique responsibilities.").

${ }^{59}$ See supra Part II.A.

${ }^{60}$ See infra notes 135-38 and accompanying text.

${ }^{61}$ S. REP. No. 97-275, at 19-21 (1981), reprinted in 1982 U.S.C.C.A.N. 11, $29-31$ (discussing Federal Circuit jurisdiction).
} 
law doctrine should not create unnecessary instability in procedural law. ${ }^{62}$ Thus, for purely procedural questions bearing no relationship to patent law, the court itself has concluded that the interests of stability in procedural law and ease of trial administration dictate deference to regional circuits. Exactly where the mandate ranks in relation to other policies is certainly a matter of debate, but one thing seems undeniable: there are instances where the court's mandate should cede to higher policies. Certainly the court's mandate is not a license to wreak havoc in other areas of jurisprudence.

\section{b. Specialized decision makers}

Although Congress explicitly refuted the perception that the Federal Circuit was a specialized court of patent appeals, ${ }^{63}$ many scholars and jurists are steadfast in their belief that patent appeals should be heard by expert judges-either expert in patent law or expert by way of their scientific or technical training. ${ }^{64}$ Even for critics of specialized courts, the notion that technically trained judges are better equipped to understand the technical issues in a patent suit can hardly be disputed. And judges who frequently hear patent appeals will presumably be more familiar with the relatively complex patent system and its doctrines.

However, neither technical training nor expertise in patent law bears on a judge's ability to rule on procedural questions. ${ }^{65}$ In fact, generalist judges might be better equipped to fit any unique procedural aspects of patent trials into the general rules of procedure. For instance, prior to the Federal Circuit's inception, regional circuits drew on their breadth of experience to square patent prosecution documents with the general policies underlying attorney-client privilege. ${ }^{66}$ When the Federal Circuit rules on attorney-client privilege, it does so from a somewhat isolated perspective, without the benefit of

${ }^{62}$ See Biodex, 946 F.2d at 857 (referring to "the core policy of not creating unnecessary conflicts and confusion in procedural matters").

${ }^{63}$ S. REP. NO. 97-275, at 6 (1981), reprinted in 1982 U.S.C.C.A.N. 11, 16 ("The Court of Appeals for the Federal Circuit will not be a 'specialized court,' as that term is normally used.").

${ }^{64}$ See, e.g., Henry J. Friendly, Federal Jurisdiction: A General View 156 (1973) (noting that "[a]nother strong argument for removing patent litigation from the ordinary courts is the increased complexity of their subject-matter").

${ }^{65}$ See Joan E. Schaffner, Federal Circuit "Choice of Law": Erie Through the Looking Glass, 81 IOWA L. REV. 1173, 1218 (1996) ("The federal court system is governed primarily by trans-substantive procedural rules ....").

${ }^{66}$ See infra notes 75-80 and accompanying text. 
having considered privilege in a broad range of legal contexts. This might cause the Federal Circuit to overemphasize the unique features of patent prosecution, ignoring analogies to attorney-client privilege in other contexts. And if a particular procedural question requires a detailed understanding of the technical facts at hand such that technical savvy might be beneficial, regardless of the choice-of-law rule used, the Federal Circuit will be the court that applies the procedural law to the technical facts at hand. So any benefit gained by having technically savvy judges hear patent suits will not be lost by deferring to regional circuit law on procedural questions.

\section{c. Keeping patent law in the mainstream of jurisprudence}

Scholars and jurists have largely overlooked the important benefits of keeping patent trials and patent law in the mainstream of jurisprudence and judicial administration. However, given that "[i]ntellectual property is central to American business," intellectual property be anywhere but in the mainstream of American jurisprudence? General counsels, generalists by definition, should be able to apply their knowledge of general litigation to as many aspects of patent trials as policy allows. And at a time when generalist litigators have become some of the most influential patent litigators ${ }^{68}$ and general practice law firms are assuming an increasingly active role in patent law, ${ }^{69}$ it is important that the skills and knowledge of generalist lawyers are easily transferable to patent law. Indeed, the less accessible patent trials are for generalists, the less likely generalists are to import their breadth of litigation experience into patent suits.

Admittedly, it may be melodramatic to surmise that divergent procedural laws will scare general practitioners from patent trials. However, any anomalies in the patent law compared to the mainstream of jurisprudence will at least further the natural reluctance that general-

${ }^{67}$ CHISUM ET AL., supra note 11, at 58.

68 Indeed, a review of any large, general practice law firm's website reveals many experienced patent litigators who have come to patent litigation from general commercial litigation. As just one example of the influence these attorneys have in patent litigation, see Bryan Rund, Who's Who in IP: Steven Friedman, LEGAL Times, May 7, 2001, at 51 (recognizing Mr. Friedman, a general commercial litigator, as one of the most influential lawyers in patent law).

69 See, e.g., Brock Moshan Gesser et AL., VAult Guide to The Top 100 LAW FIRMS 29 (7th ed. 2004) (listing six general practice firms in its prestige ranking of the top ten intellectual property firms); Tamara Loomis, Who Protects IP America, IP L. \& BUS., Dec. 2004 (noting that boutique IP firms "have been disappearing faster than one can say 'Fish \& Neave"”), available at http:/ / www.ipww.com/texts/1204/who1204.html. 
ists feel when faced with the prospect of litigating highly technical patents.

Of course, establishing a separate appellate path for patent trials presumably contributes a great deal more to this reluctance than unique procedural laws might. However, Congress found that the interest of providing uniform interpretation of infringement and validity outweighs any tendency of a centralized patent appellate system to remove patent law from the mainstream. But no such counterbalance exists with respect to procedural questions in patent trials.

In fact, even support for taking patent appeals away from the traditional federal appellate path was by no means unanimous. ${ }^{70}$ In addition to concerns about the court falling prey to the dangers of specialization, many were concerned that centralizing patent appeals would take patent law out of the mainstream of jurisprudence. ${ }^{71}$ Understandably, practitioners and patent holders rightly feared that separating patent law from mainstream jurisprudence might relegate patent rights and policy to their previous "marginal role."

\section{d. Regional variation in the law}

The Evarts Act allows each circuit to interpret federal law independently of the other circuits. ${ }^{72}$ Not only are regional variations in

${ }^{70}$ See, e.g., S. REP. NO. 97-275, at 40 (1981), reprinted in 1982 U.S.C.C.A.N. 11, 49 (additional views of Sen. Max Baucus) ("I cannot support that portion of the legislation which would remove the jurisdiction of all patent cases from the eleven Federal circuit court [sic] of appeals.”); 1979 Hearings, supra note 35, at 270 (prepared written statement of Standish F. Medina, Chairman, Committee on Federal Courts, Association of the Bar of the City of New York) ("We join a majority of the Committee on Patents of this Association and the New York Patent Law Association, Inc. in opposing the bill insofar as it relates to patents." (footnotes omitted)); Douglas B. Henderson, A View from the Patent Bar, reprinted in 1979 Hearings, supra note 35, at 641 ("The Patent Bar is badly divided over the proposed legislation.").

${ }^{71} 1979$ Hearings, supra note 35, at 541 (letter from Phillip H. Mayer of Leydig, Voit, Osann, Mayer \& Holt, Ltd.) ("Any shunting of patent law out of the mainstream of our judicial system is bound to demean the patent system."); id. at 443 (letter from Joseph M. Fitzpatrick, Chairman, Committee on Patents, The Association of the Bar of the City of New York) ("A single specialized patent appellate court is a step that will ultimately take the patent system out of the mainstream of jurisprudence."). Since the 1970 s, patent law has evolved into an important part of mainstream commercial and business law. See, e.g., Rebecca S. Eisenberg, Analyze This: A Law and Economics Agenda for the Patent System, 53 VAND. L. REV. 2081, 2081 (2000) (noting that "patent law [has] evolve[d] from an arcane, practitioner-taught specialty to a less marginal role in law school curriculums," and that "[i]nterest in patents has become sufficiently widespread to command the attention of busy world leaders").

${ }^{72}$ Act of Mar. 3, 1891, ch. 517, 26 Stat. 826; Schaffner, supra note 65, at $1175 \&$ n.11. 
our laws and government central to our conceptions of American democracy, but such variations also serve practical and theoretical interests. First, "the very diversity of our vast country, with its many regional differences and local needs, logically supports a flexible system that can benefit, when appropriate, from federal law which takes account of these regional variations." ${ }^{, 73}$ Arguably, this justification for regional variation in the law is not present, at least to any large extent, in patent trials, where litigants are typically nationwide corporations with few or no discernable regional characteristics. However, to the extent that regional variation on any legal question arising in litigation between large corporations is tolerated, so too should patent trials endure-or benefit from-such variation.

Second, regional variation in law can be beneficial because " $[\mathrm{t}] \mathrm{he}$ many circuit courts act as the 'laboratories' of new or refined legal principles ... providing the Supreme Court with a wide array of approaches to legal issues and thus, hopefully, with the raw material from which to fashion better judgments." ${ }^{74}$ Thus, allowing variation among the regional circuits serves an important function in the development of the law.

Attorney-client privilege over patent prosecution documents is a case in point. Prior to the creation of the Federal Circuit, two lines of precedent had evolved among the regional circuits regarding attorney-client privilege over patent prosecution documents. The conduit theory, stemming from Jack Winter, Inc. v. Koratron Co., ${ }^{75}$ focused on the fact that, because a patentee is required to disclose all material information to the PTO during patent prosecution, ${ }^{76}$ the attorney acts as a mere conduit for such information, passing the information from the client to the PTO. ${ }^{77}$ Under this line of cases, protection for prosecution documents, particularly ones that contained significant technical information, was limited. The other line of precedent, stemming

${ }^{73}$ J. Clifford Wallace, The Nature and Extent of Intercircuit Conflicts: A Solution Needed for a Mountain or a Molehill?, 71 CAL. L. REV. 913, 930 (1983).

${ }^{74}$ Id. at 929; see also Charles L. Black, Jr., The National Court of Appeals: An Unwise Proposal, 83 YALE L.J. 883, 898 (1974) ("Many cases of [intercircuit] conflict can be endured and sometimes perhaps ought to be endured while judges and scholars observe the respective workings-out in practice of the conflicting rules, particularly where the question of law is a close one, to which confident answer will in any case be impossible.").

50 F.R.D. 225 (N.D. Cal. 1970).

${ }^{76} 35$ U.S.C. $\$ 112(2000)$.

77 Jack Winter, 50 F.R.D. at 228. 
from Knogo Corp. v. United States ${ }^{78}$ and supported by many scholars, ${ }^{79}$ allowed somewhat broader protection for technical information, recognizing a difference between the scope of the PTO disclosure requirement and the content of communications between an attorney and her client. ${ }^{80}$

This debate among circuit and district courts is precisely the sort of discourse to which Professor Black referred. ${ }^{81}$ Only through such discourse were courts able to fully consider and resolve the policies underlying attorney-client privilege and to fit patent prosecution into its overall privilege framework.

\section{e. Forum shopping}

One of the motives for centralizing patent appeals was to reduce the perceived epidemic of forum shopping in patent suits that had arisen by the late 1970s. ${ }^{82}$ The Federal Circuit could exert its nationwide power when a particular procedural question induced excessive forum shopping in patent suits. However, in creating the Federal Circuit, Congress only addressed forum shopping caused by differing interpretations of validity and infringement among regional circuits. Even if a particular procedural rule induces forum shopping, there is no reason why patent suits should be exempt from the usual mechanisms that control forum shopping. ${ }^{83}$ Furthermore, common perceptions hold that variations in procedural law are far less likely to induce forum shopping than variations in substantive law.

\section{f. Sufficiency of precedent on procedural questions}

With the removal of nearly all patent appeals from the regional circuit courts, ${ }^{84}$ it follows that regional circuit precedent on proce-

${ }^{78} 213$ U.S.P.Q. (BNA) 936 (Ct. Cl. 1980).

79 See Jonathan G. Musch, Note, Attorney-Client Privilege and the Patent Prosecution Process in the Post-Spalding World, 81 WASH. U. L.Q. 175, 199 (2003) ("For years, various commentators ... have advocated for the adoption of the Knogo rationale, which is a more rational and useful system." (citing commentary)).

${ }^{80}$ Knogo, 213 U.S.P.Q. at 940.

${ }^{81}$ See supra note 74.

${ }^{82}$ See supra notes 42-44 and accompanying text.

${ }^{83}$ See Thomas O. McGarity, Multi-Party Forum Shopping for Appellate Review of Administrative Action, 129 U. PA. L. REV. 302, 356-71 (1980) (discussing the mechanisms that control forum shopping).

${ }^{84}$ Under the well-pleaded complaint rule, regional circuits will still hear appeals from cases where patent law is asserted as a defense to a complaint that does not allege patent law claims. "[A] case raising a federal patent-law defense does not, for that rea- 
dural issues-as the procedural rule is applied to patent trials-might cease to evolve. In other words, with the regional circuits only hearing patent issues on rare occasions, ${ }^{85}$ they will not have sufficient opportunity in the future to develop or reiterate their precedent on procedural matters in patent trials. Thus, when the Federal Circuit chooses to defer to the regional circuit courts, to the extent that it is in search of a procedural law that bears any unique relationship to patent law, the regional circuit law will be stale, if existing at all. To the extent that a procedural question has any unique relationship to patent law, the Federal Circuit might do better to rule on such questions.

To curb this problem, the Federal Circuit has announced a sensible-although criticized ${ }^{86}$-approach, by which it predicts how the regional circuit would rule on the question based on analogous precedent from the geographically appropriate circuit. $^{87}$ Of course, this approach requires the Federal Circuit to play the role of mind reader. But to the extent that it is able to find close analogies in the appropriate regional circuit court's precedent, the approach has proven workable.

\section{g. Getting the "right" answer}

Overlapping each of the concerns discussed above is the underlying goal of getting the "right" answer to procedural questions. For procedural questions, at least to some extent, the "right" answer may

\footnotetext{
son alone, 'arise under' patent law, even if the defense is anticipated in the plaintiff's complaint, and even if both parties admit that the defense is the only question truly at issue in the case." See, e.g., Christianson v. Colt Indus. Operating Corp., 486 U.S. 800, 809 (1988) (internal quotation marks omitted).

${ }^{85}$ The Supreme Court recently opened a loophole in the Federal Circuit's jurisdiction over patent appeals. See Holmes Group, Inc. v. Vornado Air Circulation Sys., Inc., 535 U.S. 826, (2002) (holding that Federal Circuit had no jurisdiction to hear an appeal where the plaintiff's well-pleaded complaint contained no issue within the Federal Circuit's jurisdiction, despite the fact that defendant's counterclaim included an allegation of patent infringement). Under Holmes, regional circuits and state courts will apparently hear appeals in at least a narrow class of patent suits. For a discussion of the potential impact this will have on patent jurisprudence, see Ravi V. Sitwala, Note, In Defense of Holmes v. Vornado: Addressing the Unwarranted Criticism, 79 N.Y.U. L. REV. 452 (2004).

${ }^{86}$ See, e.g., Kimberly A. Moore, Juries, Patent Cases, E a Lack of Transparency, 39 Hous. L. REV. 800 (2002) (criticizing the Federal Circuit's rule of deference because it requires the Federal Circuit to predict how a regional circuit would answer a particular procedural question when the regional circuit has not ruled on the question).

${ }^{87}$ See, e.g., Badalamenti v. Dunham's, Inc., 896 F.2d 1359, 1362 (Fed. Cir. 1990) (predicting how the Sixth Circuit would rule on sanctions in discovery rules).
} 
be no more than the predictable answer. But to the extent that there is a "right" answer to a procedural question, it seems that some blending of regional circuit and Federal Circuit mind power might best serve justice-combining the regional circuits' generalist perspective and breadth of experience with the Federal Circuit's potentially superior understanding of the technical facts and substantive patent law. Of course, achieving the appropriate proportions in this blend is, itself, the choice-of-law question.

\section{The EVOlution OF THE FEDERAL CirCUIT's APPROACH TO CHOICE OF Procedural LAW}

In light of the Federal Circuit's mandate to provide uniformity in substantive patent law, and the important policy concerns discussed above, this Part considers the Federal Circuit's choice-of-law precedent. Unfortunately, the court has not only supplied various standards, but has also overlooked some of the policy concerns on which its choice-of-law doctrine should be based. And perhaps most troubling is that the court often fails to consider each case in the larger context of its own choice-of-procedural-law jurisprudence or even to consider its own precedents when considering these questions. Following are discussions of three cases that are often cited for their choice-of-law analyses, spanning the evolution of the court's choice-oflaw doctrine over the last two decades.

\section{A. Panduit Corp. v. All States Plastic Manufacturing}

The first Federal Circuit opinion to address a choice-ofprocedural-law question thoroughly ${ }^{88}$ was Panduit, ${ }^{89}$ where Panduit

\footnotetext{
${ }^{88}$ The first Federal Circuit opinion that explicitly acknowledged the court's choice-of-law problem was Litton Systems, Inc. v. Whirlpool Corp., 728 F.2d 1423, 1445 (Fed. Cir. 1984), which pointed to a conflict between Eighth Circuit law and its own law regarding the standard of review for likelihood of infringement in Lanham Act cases. However, the court found it unnecessary to resolve the choice-of-law problem because the trial court's error was reversible under either standard. Id. Other early cases implicitly applied a rule of deference to regional circuit courts. See, e.g., Am. Hoist \& Derrick Co. v. Sowa \& Sons, Inc., 725 F.2d 1350, 1366-67 (Fed. Cir. 1984) (applying Ninth Circuit law to review of a Sherman Act violation, although not explicitly discussing its choice of law).

The first Federal Circuit opinion to explicitly rule on a choice-of-law problemprocedural or substantive-was In re International Medical Prosthetics Research Associates, Inc., 739 F.2d 618, 620 (Fed. Cir. 1984), where the court applied Ninth Circuit law to determine the appealability of an order disqualifying an attorney. However, the court's opinion in that case gives minimal elaboration or explanation for deferring to
} 
filed a patent infringement suit against All States Plastic Manufacturing. ${ }^{90}$ On an interlocutory appeal from Panduit's motion to disqualify All State's attorney for an alleged conflict of interest, the Federal Circuit applied Seventh Circuit law on attorney disqualification. ${ }^{91}$ The court found it important that the issue was a procedural one, and ruled "as a matter of policy, that the Federal Circuit shall review procedural matters, that are not unique to patent issues, under the law of the particular regional circuit court where appeals from the district court would normally lie." ${ }^{92}$ The court reserved its authority to rule on procedural matters that "pertain" or "relate" to "patent issues."

Thus, the court seemingly vowed to follow regional circuit precedent when the issue on appeal was a procedural issue that was not "unique" to patent law, nor "related" to "patent issues." This test immediately begged the question of when a particular procedural question is sufficiently unique or related to patent law to justify independent lawmaking by the Federal Circuit.

\section{B. Biodex Corp. v. Loredan Biomedical, Inc.}

By the early 1990s, Panduit's seemingly deferential approach had begun to erode, replaced by an ever-changing set of standards. In Biodex, ${ }^{94}$ the court faced the question of whether a postverdict motion was required to preserve appellate review of a jury verdict. ${ }^{95}$ Rather

regional circuit law, noting only that "a district court cannot and should not be asked to answer [procedural questions] one way when the appeal on the merits will go to the regional circuit ... and in a different way when the appeal will come to this circuit." Id. riam).

${ }^{89}$ Panduit Corp. v. All States Plastic Mfg., 744 F.2d 1564 (Fed. Cir. 1984) (per cu-

${ }^{90}$ Id. at 1565-67. Following Panduit, several other Federal Circuit opinions in 1984 applied a rule of deference similar to that developed in Panduit. See, e.g., Bandag, Inc. v. Al Bolser's Tire Stores, Inc., 750 F.2d 903, 909 (Fed. Cir. 1984) (“[W]e deem it appropriate here to decide nonpatent matters in the light of the problems faced by the district court from which each count originated, including the law there applicable.... [Accordingly, i] $\mathrm{n}$ the trademark portions of this case we will be guided by the relevant law in the Ninth Circuit ....”); W.L. Gore \& Assocs., Inc. v. Int'l Med. Prosthetics Research Assocs., Inc., 745 F.2d 1463, 1465-67 (Fed. Cir. 1984) (applying Ninth Circuit law to the question of attorney disqualification).

${ }^{91}$ Panduit, 744 F.2d at 1576.

${ }^{92} I d$. at $1574-75$.

${ }^{93} I d$. at 1575 n.14.

${ }^{94}$ Biodex Corp. v. Loredan Biomed., Inc., 946 F.2d 850 (Fed. Cir. 1991).

${ }^{95} I d$. at 853 . 
than deferring to regional circuit law on this procedural question, the court decided to forge its own law. ${ }^{96}$

In its analysis of this choice-of-law question, the court seemingly endorsed the meandering path that its choice-of-law precedent had taken between 1984 and 1990, reciting with some approval at least nine distinct approaches the court had taken during that time. These approaches asked, respectively, whether the procedural issue: (1) "is one 'over which this court does not have exclusive appellate jurisdiction'", ${ }^{97}$ (2) "concerns a 'subject which is not unique to patent law",;" (3) "is "not specific to our statutory jurisdiction"”; (4) "may be 'related' to 'substantive matters unique to the Federal Circuit"; ${ }^{100}$ (5) "'will come on appeal to this court [in most cases involving the issue]" thereby putting us in a 'good position to create a uniform body of federal law' on the issue"; ${ }^{101}$ (6) is one for which "there is existing and expressed uniformity among the circuits," in which case "we have generally conformed our law to that of the regional circuits, without regard to the relationship of the issue to our exclusive jurisdiction"; ${ }^{102}$ (7) "involves an interpretation of the Federal Rules of Civil Procedure or the local rules of the district court"; ${ }^{103}$ (8) "involv[es] substantive matters unique to the Federal Circuit," in which case "we apply to related procedural issues the law of this circuit"; ${ }^{104}$ and finally, (9) goes "to our own appellate jurisdiction., ${ }^{105}$

To this list the court adds additional considerations, including whether the issue "bears an essential relationship to matters committed to our exclusive control by statute, the appellate review of patent trials,"

${ }^{96}$ See id. at 859 ("[W]e conclude that deference to regional circuit law is not appropriate in this case.").

${ }^{97} I d$. at 855-56 (quoting Cicena Ltd. v. Columbia Telecomms. Group, 900 F.2d 1546, 1548 (Fed. Cir. 1990)).

${ }^{98}$ Id. at 856 (quoting Kalman v. Berlyn Corp., 914 F.2d 1473, 1480 (Fed. Cir. 1990)).

${ }^{99}$ Id. (quoting Registration Control Sys. v. Compusystems, Inc., 922 F.2d 805, 807 (Fed. Cir. 1990)).

${ }^{100}$ Id. (quoting Chrysler Motors Corp. v. Auto Body Panels of Ohio, Inc., 908 F.2d 951, 953 (Fed. Cir. 1990)).

${ }^{101}$ Id. (quoting Forman v. United States, 767 F.2d 875, 880 n.6 (Fed. Cir. 1985)).

${ }^{102}$ Id. (citing, inter alia, Wahpeton Canvas Co. v. Frontier, Inc., 870 F.2d 1546, 1552 n.8 (Fed. Cir. 1989))

${ }^{103} I d$. at 857 (citing, inter alia, Kalman, 914 F.2d at 1480).

${ }^{104}$ Id. at 858 (quoting Chrysler, 908 F.2d at 953).

${ }^{105}$ Id. (citing, inter alia, Woodard v. Sage Prods., Inc., 818 F.2d 841, 844 (Fed. Cir. 1987) (en banc))

${ }^{106} I d$. at 858-59. 
evidence is submitted and the verdict rendered," such "that district courts [would] not be required to apply two sets of ... procedural laws during trial., ${ }^{107}$ Additionally, the court seems to have explicitly rejected the importance of Panduit's "unique to" patent law language, finding that the court will not defer to regional circuits "merely because [the procedural] issue might separately arise in a case having nothing to do with the patent laws." ${ }^{108}$ At this point, then, litigants and district courts were left with virtually countless formulations of the Federal Circuit's choice-of-procedural-law doctrine.

Ultimately, the Biodex court seems to have based its ruling on the holding that review of a jury verdict in a patent suit bears an essential relationship to patent law. However, after deciding to create its own law because of this "essential relationship" to appellate review of patent trials, the court's subsequent reasoning on the procedural question itself bears no relationship to appellate review of patent trials per se-its reasoning is in no way unique, related, or essential to patent law-but is instead equally applicable to any appellate court's review of any legal question. ${ }^{109}$ One must question whether the court would apply the same test if asked to review a jury verdict on a contract claim that came before the Federal Circuit as an ancillary claim to a patent suit - the suit on appeal would still be a patent suit appealed from the district court, and the question on appeal would still be whether a postjury motion is a prerequisite to appellate review of the jury verdict in a patent suit. But in such a case, the relationship to appellate review of patent trials becomes even further attenuated.

Furthermore, by focusing on the phrase "appellate review of patent trials," nearly any procedural question could be framed as "bearing an essential relationship to patent trials." Thus, the Biodex test suffers from ambiguity because it wholly depends on the level of abstraction with which the court considers a particular issue. Review of a jury verdict on the question of patent validity can be said to bear the essential relationship, while the alternatively phrased review of a jury verdict might not.

${ }^{107}$ Id. at 859 .

108 Id. at 858 .

109 In ruling that a postverdict motion is a prerequisite to appellate review of a jury verdict, the court focuses on the fact that such motions are not unreasonably burdensome, and are important because they illuminate the trial judge's insight into trial events and the credibility of the evidence presented at trial. Id. at 859-62. Each of the reasons given is equally applicable to any civil trial where the trial judge hears testimony and observes trial events along with the jury. 
In addition to these proposed tests, the court recites a number of policy objectives that should guide the application of any choice-of-law standard: "the policy of achieving uniformity in district court management of trials"; $;{ }^{110}$ the goal of enhancing "[u]niformity in the review of patent trials"; conflicts and confusion in procedural matters."

\section{In re Spalding Sports Worldwide, Inc.}

During the decade after Biodex, the meandering path of the Federal Circuit's choice-of-procedural-law precedent continued. In Spalding, ${ }^{113}$ the court, as in Biodex, cited a variety of potential standards; and then, again as in Biodex, added to the list of potential considerations. At issue in Spalding was discovery of an invention record submitted by two inventors to their company's legal department. ${ }^{114}$ Wilson Sporting Goods, Co., defending infringement allegations brought by Spalding, contended that the invention records were not covered by attorney-client privilege, and that even if these records were so protected, Spalding could be compelled to produce them under a crimefraud exception theory-more specifically, that attorney-client privilege should be pierced because Spalding had allegedly committed fraud on the PTO by failing to disclose material information during patent prosecution.

The court rejected the suggestion that it defer to regional circuit law, holding instead that the issue on appeal- "whether the invention record is protected by the attorney-client privilege"-is "unique to patent law[,] ... clearly implicates substantive patent law," 115 and "bears an essential relationship to matters committed to our exclusive [jurisdiction] by statute." 116 The implications of attorney-client privilege on inequitable conduct were apparently sufficient to warrant unique procedural law. ${ }^{117}$

Thus, the court's choice-of-law ruling seemed to hinge on two factors: first, that an invention record, submitted to corporate counsel

110 Id. at 856.

111 Id. at 859.

112 Id. at 857.

113 In re Spalding Sports Worldwide, Inc., 203 F.3d 800 (Fed. Cir. 2000).

114 Id. at 802.

115 Id. at 804.

$116 I d$. at 803 (alteration in original) (quoting Midwest Indus. v. Karavan Trailers, Inc., 175 F.3d 1356, 1359 (Fed. Cir. 1999) (en banc in relevant part)).

117 Id. at 803. 
for the purpose of obtaining a patent, is unique to patent law; and second, that the issue on appeal implicated the substantive patent issue of inequitable conduct. Admittedly, these two bases could be gleaned from the Federal Circuit's precedent (even though Biodex had undermined the importance of whether a particular question was unique to patent law). However, just like the test applied in Biodexi.e., whether the issue bears an essential relationship to appellate review of patent trials-Spalding's test hinges on the level of abstraction with which the court chooses to view a question. If the question is phrased as whether an allegation of fraud on the PTO can be sufficient to overcome privilege on an invention record submitted for the purpose of obtaining a patent, then the strong relationship to patent law seems plausible. Alternately though, the analysis could be broken into two questions: first, whether the documents are covered by attorney-client privilege; and second, whether that privilege should be pierced in light of the alleged inequitable conduct. Framed in this way, the first of these two steps bears no more than a tenuous relationship to patent law.

\section{The Federal Circuit's Continued Failure to Consider an "Essential Relationship" Spectrum}

Beyond the numerous standards discussed above, the Federal Circuit has used still other phrasing and reasoning to enunciate its choice-of-law rule. For instance, in Flex-Foot, Inc. v. CRP, Inc., ${ }^{118}$ the court, with seeming definitiveness, stated that it "will apply [its] own law to both substantive and procedural issues "intimately involved in the substance of enforcement of the patent right." "119 And perhaps the most commonly reiterated test during the last five years is an amalgamation of several previous standards:

[The Federal Circuit] appl[ies] regional circuit law to procedural issues that are not themselves substantive patent law issues so long as they do not (1) pertain to patent law, (2) bear an essential relationship to matters committed to [the court's] exclusive control by statute, or (3) clearly implicate the jurisprudential responsibilities of [the court] in a field within its exclusive jurisdiction.

\footnotetext{
118238 F.3d 1362 (Fed. Cir. 2001).

${ }^{119}$ Id. at 1365 (quoting Amana Refrigeration, Inc. v. Quadlux, Inc., 172 F.3d 852, 856 (Fed. Cir. 1999) (citation omitted)).

${ }^{120}$ Int'l Nutrition Co. v. Horphag Research Ltd., 257 F.3d 1324, 1328 (Fed. Cir. 2001) (citation omitted).
} 
The problem with the court announcing so many formulations of its rule is not simply one of semantics. In applying its various choiceof-law rules, the Federal Circuit has reached seemingly contradictory results. For instance, if the Spalding court had followed the Panduit rule, it likely would have found that the attorney-client privilege question was not sufficiently "unique" or "related" to patent law to warrant ignoring regional circuit law-attorney-client privilege, even for patent documents, can arise in nearly any litigation. Thus, the reality is that the outcome of a particular choice-of-law question hinges on which of the various standards the court chooses to employ in a particular case. And there is little discernible logic to the court's selection of a particular test in a given case.

But most troubling is that the court often fails to consider each case in the larger context of its choice-of-procedural-law jurisprudence. For instance, in Ferguson Beauregard/Logic Controls v. Mega Systems, $L L C,{ }^{121}$ the plaintiff sought to amend its complaint with a claim of willful infringement. ${ }^{122}$ The district court denied this motion, holding that willful infringement was subject to heightened pleading requirements under Federal Rule of Civil Procedure 9(b). ${ }^{123}$ In reversing the district court's denial of the plaintiff's motion, the court noted that its "review of the denial of a motion to amend a complaint is determined by the regional circuit's standard which, in the Fifth Circuit, is abuse of discretion."

Just two years earlier, in Advanced Cardiovascular Systems, Inc. v. Medtronic, Inc. ${ }^{125}$ the defendant sought to amend its response with a counterclaim of invalidity. ${ }^{126}$ The court concluded that "we review the district court's refusal to allow [defendant's] amendment to the pleadings under Federal Circuit law." ${ }^{127}$ In doing so, the court reasoned that " $[\mathrm{d}]$ etermining the sufficiency of notice regarding defenses asserted under specific statutory provisions of the patent laws clearly implicates the jurisprudential responsibilities of this court."128 Of course, willful infringement, which the plaintiff in Ferguson Beaure-

\footnotetext{
121350 F.3d 1327 (Fed. Cir. 2003).

${ }^{122} I d$. at 1342.

${ }^{123} I d$.

${ }^{124} I d$.

265 F.3d 1294 (Fed. Cir. 2001).

${ }^{126} I d$. at 1303 .

${ }^{127} \mathrm{Id}$.

${ }^{128} I d$. (emphasis added).
} 
gard sought to add to its claim, is also governed by a specific statutory provision within the patent laws. ${ }^{129}$

Perhaps Ferguson Beauregard and Advanced Cardiovascular are distinguishable. But given the similarity of the procedural questions presented in the two cases (i.e., the ability of a party to amend its pleading), the court should have considered Advanced Cardiovascular when it faced Ferguson Beauregard. Unfortunately, the court fails even to cite Advanced Cardiovascular in its Ferguson Beauregard opinion.

This is but one example where the Federal Circuit failed to consider highly relevant precedent. In fact, Ferguson Beauregard involves another example. In Ferguson Beauregard the court also reviewed the district court's denial of the plaintiff's motion to amend its complaint with a charge of inequitable conduct, after the district court found its initial pleading insufficient to claim inequitable conduct. ${ }^{130}$ The district court's holding, the Federal Circuit noted, was "essentially a conclusion that Ferguson has failed to state a claim upon which relief may be granted." ${ }^{311}$ Just as with the other motion in Ferguson Beauregardthe plaintiff's motion to amend its complaint to allege willful infringement-the Federal Circuit deferred to Fifth Circuit law in reviewing the district court's denial. But recall Spalding. ${ }^{132}$ There, the court held that attorney-client privilege over patent prosecution documents-at least with respect to the facts of that case-should be governed by Federal Circuit law because the case implicated "the substantive patent issue of inequitable conduct." ${ }^{\text {"33 }}$

Unfortunately, Ferguson Beauregard fails to cite or discuss Spalding. Taken together, these two cases stand for the strange proposition that the sufficiency of a party's inequitable conduct pleading-a question that goes to the heart of inequitable conduct-does not implicate the substantive patent issue of inequitable conduct to the same extent as attorney-client privilege.

By failing to consider each case in relation to similar cases, the precedential value of each case is minimized. Furthermore, by neglecting to fit each case into any larger context or framework, the evolution of the court's choice-of-law doctrine is rendered meandering and conflicted rather than systematic and deliberate. Each case pro-

${ }^{129}$ See 35 U.S.C. $\$ 271$ (a) (2000) (defining patent infringement).

${ }^{130}$ Ferguson Beauregard, 350 F.3d at 1343.

${ }^{131} I d$. at 1344.

${ }^{132}$ In re Spalding Sports Worldwide, Inc., 203 F.3d 800 (Fed. Cir. 2000); see also supra Part III.C.

${ }^{133}$ Spalding, 203 F.3d at 803-04. 
vides a single data point of precedent, but litigants are left with no way to place that data point in relation to their own cases.

The implicit conclusion, then, is that each individual case will be decided not in reference to a single guiding standard or even a conglomeration of factors and case precedent, but rather on its own particular facts. And those facts may be held to one of many potential standards. Even reference to precedent on the same procedural question may not be dispositive. ${ }^{13-}$

\section{SUgGeSTIONS FOR REFORM OF THE FEDERAL CiRCUIT'S CHOICE-OF-LAW DOCTRINE}

\section{A. Previous Scholarship}

Mine is not the first look at the need for change in the Federal Circuit's choice-of-law doctrine. ${ }^{135}$ Much of the prior scholarship on this issue has concluded that "the Federal Circuit should apply its

${ }^{134}$ Compare In re Pioneer Hi-Bred Int'l, Inc., 238 F.3d 1370, 1374 (Fed. Cir. 2001) (applying Eighth Circuit law to the question of attorney-client privilege over information pertaining to patent licensing agreements), with Spalding, 203 F.3d at 804 (applying Federal Circuit law to the question of attorney-client privilege over patent prosecution documents); compare also Amana Refrigeration, Inc. v. Quadlux, Inc., 172 F.3d 852 857 (Fed. Cir. 1999) (applying Eighth Circuit law to the question of personal jurisdiction in a case involving unfair competition claims), with 3D Sys., Inc. v. Aarotech Labs., Inc., 160 F.3d 1373, 1377-78 (Fed. Cir. 1998) (applying Federal Circuit law to the question of personal jurisdiction in a case involving unfair competition claims because these claims went "hand-in-hand with [the] patent infringement claims").

${ }^{135}$ See Schaffner, supra note 65, at 1178 ("This Article develops a new Federal Circuit 'choice of law' doctrine derived from the congressional goals in creating the Federal Circuit."). Although Professor Schaffner's analysis is the most comprehensive review of the Federal Circuit's choice-of-law problem, other scholars have addressed and commented on the issue at least in passing. See, e.g., Dreyfuss, supra note 58, at 61 (discussing the impact of the choice-of-law doctrine on the Federal Circuit's goals as a specialized court); Moore, supra note 86, at 800 (discussing the Federal Circuit's choice-oflaw problem in relation to reviewing jury verdicts); Rogers, supra note 15, at 438-42 (discussing the interplay between the Federal Circuit's choice-of-law doctrine and the court's "arising under" jurisdiction). For further discussion of the Federal Circuit's choice-of-substantive-law doctrine, see James B. Gambrell, The Evolving Interplay of Patent Rights and Antitrust Restraints in the Federal Circuit, 9 TEX. INTELL. ProP. L.J. 137 (2001).

It should be noted that the approach proposed infra Part IV.B is somewhat similar to that proposed, in passing, by Professor Rogers. See Rogers, supra note 15, at 472 (suggesting that a potential bright-line rule might be for the Federal Circuit to exercise independent judgment only "if [it] is interpreting the meaning of patent-related federal common law or a patent law statute"). However, the focus of Professor Rogers's article is the jurisdictional grant of the Federal Circuit, and she only devotes a single paragraph to considering a potential choice-of-law rule. Id. at 472. 
own law to all procedural issues arising in patent cases." ${ }^{\text {136 }}$ But calls for such an expansive scope of Federal Circuit judgment either fail to consider the Federal Circuit's mandate in relation to other fundamental policies ${ }^{137}$ or overstate the scope of the Federal Circuit's mandate. ${ }^{138}$

Reaching a more moderate conclusion, Professor Schaffner has provided the most comprehensive consideration of the Federal Circuit's choice-of-law doctrine. Schaffner proposes that "the Federal Circuit should exercise independent jurisdiction over all legal issues that either (1) impact upon the patent-related primary activities of the parties or (2) relate to patent policy and thus invoke the special expertise of the Federal Circuit." ${ }^{139}$ It seems that this test, however, would allow the Federal Circuit to continue exercising expansive independent judgment over so many procedural issues-privilege, attorney disqualification, personal jurisdiction, etc.- that could be said to affect the patent-related primary activities of parties. ${ }^{140}$ As suggested in Part III of this Comment, a comprehensive view of all interests affected by the Federal Circuit militates toward a much less expansive role for the Federal Circuit in creating procedural law.

Furthermore, in developing her proposal, Professor Schaffner focuses on "two fundamental considerations: (1) the desire for uniformity in the treatment of 'like cases' and (2) the interests of the

${ }^{136}$ Moore, supra note 86, at 800; see also id. at 801 ("I find the Federal Circuit's current choice of law rules unsatisfying and believe this avenue is ripe for further research into whether a blackletter rule-wherein Federal Circuit law would apply to all procedural issues in patent cases-might be superior to the current choice of law rules."); Dreyfuss, supra note 58, at 61-64 (arguing that the Federal Circuit should independently decide procedural questions arising in patent trials).

${ }^{137}$ See, e.g., Rogers, supra note 15 , at 472 (referring only to the policy goals of achieving uniformity in the patent law and reducing forum shopping).

${ }^{138}$ See, e.g., Dreyfuss, supra note 58, at 64 (misconstruing the Federal Circuit's mandate to suggest that " $[\mathrm{i}] \mathrm{f}$ it is to be a court that oversees technological progress," the court "must ... drop its reluctance to construe federal law independently"); Schaffner, supra note 65, at 1210 (suggesting that the Federal Circuit's mandate is to "[p]rovid[e] uniform guidance to patent-related business decisions[, which] goes beyond the uniform development of the substantive patent laws").

${ }^{139}$ Schaffner, supra note 65, at 1179.

${ }^{140}$ Although Professor Schaffner suggests that "the Federal Circuit currently exercises independent judgment over certain procedural issues that have little or no impact on patent policy or the patent-related primary activities of the parties," $i d$. at 1179, her proposed test would seemingly leave the Federal Circuit free to continue this overexpansive review of procedural questions. See id. at 1219 ("Under this thesis ... the Federal Circuit exercises independent judgment over procedural rules that affect the substantive rights of the litigants or involve substantive patent policy and the expertise of the court."). 
Federal Circuit and the regional courts." ${ }^{\text {141 }}$ Although capturing the issues discussed in the Federal Circuit's decisions, these two considerations miss many of the policy concerns discussed above. ${ }^{142}$ Again, on the whole, these additional policy concerns weigh in favor of deference to regional circuit law on procedural questions and bright-line choice-of-law decisions.

\section{B. Suggestions for Reform}

Throughout the many standards the Federal Circuit has announced and applied in choice-of-procedural-law analyses, the underlying aim is almost always the same: finding the proper line of demarcation between Federal Circuit law and regional circuit law. ${ }^{143}$ The court's most familiar language, "bears an essential relationship to" patent law, ${ }^{144}$ suggests as much—a search for the breaking point, where the impact of a particular procedural question on substantive patent law becomes sufficiently essential to warrant the Federal Circuit's meddling with procedural law despite the risk that such meddling will introduce uncertainty.

Instead of consistently approaching procedural questions with a single line of demarcation, however, the court has attempted to define numerous lines. In one case the line is defined in terms of the Federal Rules of Civil Procedure $;{ }^{145}$ in another it is defined in terms of "uniqueness" of the procedural question. ${ }^{146}$ By focusing on a single line of demarcation and conceptualizing the space inside and outside this line as a spectrum with varying degrees of relations to patent law, the Federal Circuit could bring a consistent framework, and thereby

${ }^{141} I d$. at 1179. The "essential relationship" spectrum proposed in this Comment is intended to ensure that the Federal Circuit adheres to the first of these two fundamental considerations.

${ }^{142}$ See supra Part II.B (discussing the impact of the choice-of-law doctrine on "potential litigants, courts, and the effectiveness and quality of the law itself").

${ }^{143}$ In at least one formulation, however, the court loses sight of this aim. See, e.g., Biodex Corp. v. Loredan Biomed., Inc., 946 F.2d 850, 856 (Fed. Cir. 1991) (noting that "when there is existing and expressed uniformity among the circuits," "we have generally conformed our law to that of the regional circuits, without regard to the relationship of the issue to our exclusive jurisdiction").

${ }^{144} I d$. at 858-59.

${ }^{145}$ See, e.g., id. at 857 ("[O] $[\mathrm{O}$ practice has been to defer to regional circuit law when the precise issue involves an interpretation of the Federal Rules of Civil Procedure.").

${ }^{146}$ See, e.g., Kalman v. Berlyn Corp., 914 F.2d 1473, 1480 (Fed. Cir. 1990) ("In review of an order denying a motion to amend, a subject which is not unique to patent law, we look to the law of the regional circuit court."). 
enhanced predictability, to its choice-of-procedural-law doctrine. At one end of this "essential relationship" spectrum are questions that bear no relationship to patent law. At the other end are questions that are themselves substantive patent law questions. Somewhere between these polar endpoints is the essential relationship point of demarcation.

When the Federal Circuit faces a choice-of-procedural-law question, it should strive to place the particular procedural question in its proper place, relative to other points on this conceptual spectrum. In this way, each decision becomes a guidepost for future choice-of-law questions. For instance, given the court's choice of law in Spalding, if the court were to face the question posed in Ferguson Beauregard, it would be forced to consider where on the spectrum Ferguson Beauregard should be placed relative to Spalding. The question for the court would then be: compared to attorney-client privilege (addressed in Spalding), does the sufficiency of an inequitable conduct pleading (addressed in Ferguson Beauregard) bear more or less on the substantive patent law of inequitable conduct? In other words, the relevant unit of measure along this spectrum is the degree to which a particular procedural question bears on substantive patent law. The key benefit of this conceptual framework, then, is that it would foster a more workable and predictable framework for choice-of-procedural-law problems by forcing the Federal Circuit to fit each procedural question into the larger context of the court's choice-of-procedural-law jurisprudence.

To reap the future benefits of this framework, the court should adopt relatively bright and immovable data points on the essential relationship spectrum, to foster predictability. If, in one case, the Federal Circuit finds that personal jurisdiction is a regional circuit question, then, absent some clear and compelling distinguishing characteristics, the court should defer to regional circuit precedent for all subsequent personal jurisdiction questions. The court should not create its own body of personal jurisdiction law in one case and then defer to regional circuit personal jurisdiction law in another. ${ }^{147}$ This is a case where the benefits of adherence to form over substance outweigh the dangers. So long as the Federal Circuit maintains its role as the guid-

${ }^{147}$ In the past, when faced with the question of jurisdiction, the court has deferred to regional circuit law in some cases, and forged its own law in other. See, e.g., supra note 134 (identifying just such an inconsistency concerning the procedural law used in unfair competition claims, between Amana, applying regional circuit law, and 3D Systems, applying Federal Circuit law). The same inconsistency is true of attorney-client privilege. See supra note 134. 
ing voice on issues of validity and infringement, bright-line choice-oflaw decisions will promote the policies discussed in Part III without unduly sacrificing the Federal Circuit's mandate.

Of course, the question remains: where is the "essential relationship" point on this spectrum (i.e., where is the line of demarcation between the proper realm of the Federal Circuit and the regional circuits)? The Federal Circuit should account for all relevant policy concerns in defining this point of demarcation. While the goals of uniformity in procedural law and substantive patent law may be of primary importance, other policy concerns should at least enter the analysis. And, as discussed in Part III, the goal of achieving uniformity in substantive patent law is the only goal furthered when the Federal Circuit independently judges procedural questions. Under the current approach, uniformity in procedural law is sacrificed, patent trials are moved further from the mainstream of jurisprudence, the district courts' management of trials is complicated, appellate review is complicated, and the development of procedural law for patent trials is put at risk of specialization.

Consequently, when searching for the line of demarcation on the essential relationship spectrum, the Federal Circuit should give maximum deference to regional circuit precedent and substantially limit its own independent judgment on procedural questions. Regional circuits are better equipped to handle procedural questions, particularly given the precarious role in which district court judges are cast when the Federal Circuit chooses to independently decide a procedural question. The only instances where the Federal Circuit might justify independent rulings on procedural questions are those where the procedural question at issue directly affects the predictability of validity and infringement interpretations - the very core of the court's mandate. Questions that merely relate to patent law should not invoke unique procedural law by the Federal Circuit.

According to this proposal, attorney-client privilege, personal jurisdiction, and myriad other procedural questions should be resolved under regional circuit precedent. Although this proposal might shift many of the Federal Circuit's current choice-of-law decisions toward deference to regional circuit law, my proposal is for maximum deference, not total deference. Certainly there are procedural questions that sufficiently implicate the predictability of validity and infringement interpretations to warrant Federal Circuit precedent. For instance, jury instructions are one category of procedural question for which the Federal Circuit has appropriately recognized a sufficient 
impact on the predictability of validity and infringement. ${ }^{148}$ The sufficiency of jury instructions on complicated patent doctrines can directly implicate validity and infringement law.

Under this proposal, the court should be able to uphold its mandate to facilitate uniformity in the law of patent validity and infringement, while minimizing the disruption to procedural law and keeping patent suits as close to the mainstream of jurisprudence as possible. Most importantly, by considering choice-of-procedural-law questions with reference to an essential relationship spectrum, each choice-ofprocedural-law question will bring further clarity to the choice-of-law problem, rather than, as has often been the case, further confusing the problem.

\section{CONCLUSION}

Just as " $[t]$ he businessman wants to know if a patent is likely to be sustained or overturned and not that his chances are at one percentage level if the trial occurs in one circuit and at another percentage level if it occurs in another circuit," ${ }^{149}$ so too does the businessperson want to know whose law of privilege or personal jurisdiction will apply in future litigation. Under the current path of the Federal Circuit's choice-of-law doctrine, finding predictability is elusive if not impossible. What is missing is a consistent conceptual framework. This Comment proposes such a framework, in the form of a conceptual spectrum, along which each choice-of-procedural-law question should be placed, with past decisions serving as guideposts along the spectrum. No matter what framework is chosen, when the Federal Circuit looks at procedural questions it should consider the full range of relevant policies, and in doing so arrive at stable, bright-line decisions giving maximum deference to regional circuit law. Only when a procedural question directly affects the predictability of invalidity or infringement interpretations should the Federal Circuit create its own body of procedural law.

\footnotetext{
148 See, e.g., Sulzer Textil A.G. v. Picanol N.V., 358 F.3d 1356, 1363 (Fed. Cir. 2004) (applying Federal Circuit law on a jury instruction question); Arlington Indus. v. Bridgeport Fittings, Inc., 345 F.3d 1318, 1325 (Fed. Cir. 2003) (same).

${ }_{149}$ Addendum to 1979 Hearings, supra note 35, at 67 (statement of Harry F. Manbeck, Jr., general patent counsel of General Electric Co.).
} 